\title{
Modeling the effect of plume-rise on the transport of carbon monoxide over Africa with NCAR CAM
}

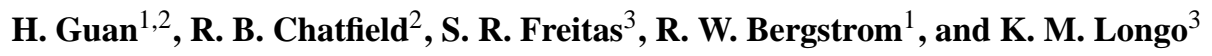 \\ ${ }^{1}$ Bay Area Environmental Research Institute, Sonoma, CA, USA \\ ${ }^{2}$ NASA Ames Research Center, Moffett Field, CA, USA \\ ${ }^{3}$ Center for Weather Forecasting and Climate Studies (CPTEC), INPE, Cachoeira Paulista, Brazil \\ Received: 21 September 2007 - Published in Atmos. Chem. Phys. Discuss.: 18 December 2007 \\ Revised: 13 October 2008 - Accepted: 16 October 2008 - Published: 27 November 2008
}

\begin{abstract}
We investigated the effects of fire-induced plumerise on the simulation of carbon monoxide (CO) over Africa and its export during SAFARI 2000 using the NCAR Community Atmosphere Model (CAM) with a CO tracer and a plume-rise parameterization scheme. The plume-rise parameterization scheme simulates the consequences of strong buoyancy of hot gases emitted from biomass burning, including both dry and cloud-associated (pyro-cumulus) lofting. The current implementation of the plume-rise parameterization scheme into the global model provides an opportunity to examine the effect of plume-rise on long-range transport. The CAM simulation with the plume-rise parameterization scheme seems to show a substantial improvement of the agreements between the modeled and aircraft-measured vertical distribution of $\mathrm{CO}$ over Southern Africa biomassburning area. The plume-rise mechanism plays a crucial role in lofting biomass-burning pollutants to the middle troposphere. In the presence of deep convection we found that the plume-rise mechanism results in a decrease of CO concentration in the upper troposphere. The plume-rise depletes the boundary layer, and thus leaves lower concentrations of $\mathrm{CO}$ to be lofted by the deep convection process. The effect of the plume-rise on free troposphere $\mathrm{CO}$ concentration is more important for the source area (short-distance transport) than for remote areas (long-distance transport). A budget analysis of CO burden over Southern Africa reveals the plume-rise process to have a similar impact as the chemical production of $\mathrm{CO}$ by $\mathrm{OH}$ and $\mathrm{CH}_{4}$. In addition, the plume-rise process has an minor impact on the regional export. These results further confirm and extend previous findings in a regional model study. Effective lofting of large concentration of $\mathrm{CO}$
\end{abstract}

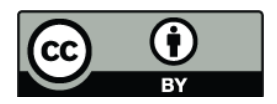

Correspondence to: $\mathrm{H}$. Guan (hong.guan-1@ nasa.gov) by the plume-rise mechanism also has implications for local air quality forecasting in areas affected by other fire-related pollutants.

\section{Introduction}

Carbon Monoxide (CO) is one of the principal pollutants in the atmosphere and has an important impact on the chemical production of tropospheric ozone. CO has been used as a tracer indicative of incomplete combustion, enabling the tracking of long-distance transport (Pickering et al., 1996; Wang et al., 1996; Li et al., 2005; Staudt et al., 2001; Bey et al., 2001; Sinha et al., 2004; Chatfield et al., 1998; Freitas et al., 2006; Damoah et al., 2006; Duncan et al., 2007). The biomass burning of natural vegetation is a significant source of CO in Central and Southern Africa (Hao et al., 1990; Andreae, 1991; Matichuk et al., 2007). During the dry season, farmers across the region burn savanna and forest to clear land and revitalize the soil. The region is subject to some of the highest levels of biomass burning emissions in the world during August-September.

Biomass burning releases a large amount of thermal energy that creates a strong updraft. This updraft has a huge impact on tracer distributions through a direct and rapid injection into the free troposphere as well as the stratosphere (Fromm et al., 2000; Jost et al., 2004; Freitas et al., 2006; Rosenfeld et al., 2007). Various models (Liousse et al., 1996; Freitas et al., 2006; Turquety et al., 2007; Matichuk et al., 2007; Wang et al., 2006) have estimated the impact of the biomass burning on simulated $\mathrm{CO}$ or aerosol distributions. However, most of the researchers assumed a constant injection-height in their simulation domains. For example, Wang et al. (2006) assumed an injection-height of $1.2 \mathrm{~km}$ in

Published by Copernicus Publications on behalf of the European Geosciences Union. 
their mesoscale modeling of Central America smoke transport. Similarly, Matichuk et al. (2007) used various constant injection heights within the study domain to examine the sensitivity of injection height on aerosol optical depth during the Southern African Regional Science Initiative (SAFARI 2000) (Swap et al., 2003). Previous studies suggest values of injection height that range from $1.2 \mathrm{~km}$ for Central American fires to $8 \mathrm{~km}$ in Canadian intensive "crown" fires (Wang et al., 2006). Theory and observation suggest that the actual injection height depends on environmental conditions (stability, the amount of water vapor, and wind speed), heat flux (Freitas et al., 2006) and the size of the fire, and thus the use of constant injection height in global models is not realistic. An accurate injection height for biomass burning emissions is of fundamental importance for plume transport and therefore we need a more accurate way to calculate the correct injection height for biomass burning.

Recently, Freitas et al. (2006, 2007b) implemented a plume-rise parameterization scheme in the CATT-BRAMS model (the Coupled Aerosol and Tracer Transport model to the Brazilian developments on the Regional Atmospheric Modeling System) and demonstrated the impact of the plume-rise mechanism on the regional model simulation. In this study, we illustrate the regional effects of plume-rise parameterization on the vertical distribution of $\mathrm{CO}$ and its export to the Atlantic Ocean and Indian Ocean by a global model. The "Great Africa Plume" (Chatfield et al., 1998) and "River of Smoke" (Sinha et al., 2004) are two important plume events and export pathways during the dry season. Our 13-day simulations capture the two major events observed during the SAFARI 2000 Dry Season Campaign of September 2000 (Swap et al., 2003). These events involved relatively short-range transport from the sources in Southern Africa and so 13-day simulations with one-year spin-up appears sufficient for the details we sought.

This paper is organized as follows: the three dimensional (3-D) global model and implementations of CO chemistry and plume-rise parameterization schemes are summarized in Sect. 2; model results are compared to ground-based, aircraft, and MOPITT (Measurements Of Pollution In The Troposphere) satellite measurements in Sect. 3; in Sect. 4, the effects of the plume-rise mechanism on the $\mathrm{CO}$ budget over Southern Africa and the export to the Southern Atlantic and Indian Oceans are examined, and finally a summary is given in Sect. 5.

\section{Model description}

The model used in this study is an offline version of the NCAR CAM3.1 and a complete description can be found from the NCAR website at (http://www.ccsm.ucar.edu/ models/atm-cam/docs/description/description.pdf). Here we only highlight the main features and modifications to the model. The CAM is a global general circulation model that can run in three different dynamical cores. In this work, we have chosen the finite volume (FV) dynamical core (Lin, 2004) since Rasch et al. (2006) have demonstrated that the FV dynamical core is conservative, less diffusive, and maintains the nonlinear relationships among variables required by thermodynamic and mass conservation constraints more accurately compared to the other two dynamical cores (spectral and semi-Lagrangian cores). In addition to the new implementation of the plume-rise scheme, the vertical transport processes of tracer gases also include larger-scale vertical motion, deep convection (Zhang and McFarlane, 1995), and vertical turbulent mixing (Holtslag and Boville, 1993). The model employs a $2^{\circ} \times 2.5^{\circ}$ regular latitude/longitude grid with 26 vertical layers, having a model top layer located at between 2 and $4 \mathrm{hPa}$. The meteorological fields used to drive the model were obtained from the NCEP (National Center for Environmental Prediction) reanalysis with 6-h resolution (Kalnay et al., 1996). The 13-day simulation was performed from 1 September 2000 until 13 September 2000. The initial conditions were created from a one-year spin-up simulation driven by the NCEP meteorological data.

\section{$2.1 \quad$ CO chemistry}

The 3-D source of $\mathrm{CO}$ throughout the atmosphere results from the reaction between hydroxyl radicals $(\mathrm{OH})$ and methane. The major sink of $\mathrm{CO}$ occurs through its reaction with $\mathrm{OH}$. Similar to the recent work by Arellano et al. (2007), we neglect the CO source due to oxidation of nonmethane hydrocarbons (NMHCs), which is expected to have a small effect on the transport mechanism study. We simulated the sink with a monthly averaged $\mathrm{OH}$ data generated from GMI/GISS (Goddard Institute of Space Science) simulations with a full chemistry model. The monthly surface emissions include fossil fuel, biofuel, biomass burning, continental biogenic and oceanic net sources, which were derived by Pétron et al. (2004) based on an inverse modeling method using the MOPITT data for each specific month.

Emissions from biomass burning are a large source of $\mathrm{CO}$ over the tropical and subtropical regions (Crutzen et al., 1979; van der Werf et al., 2006), and highly variable in time and space. The monthly averaged biomass burning emissions, which have been used by many previous researchers, cannot represent fires that last just a fraction of month. For example, Chin et al. (2007) attributed the missed high black and organic carbon episode in their GOCART (Goddard Chemistry Aerosol Radiation and Transport) simulation to the coarser time resolution of emission data (monthly fire emission data). To account for the day-to-day variation of biomass burning CO emissions, we used the Terra-MODIS (the MoDerate Resolution Imaging Spectroradiometer) daily fire count data as a proxy. Fire detections are determined using MODIS's thermal band twice a day (10:30 a.m. and 10:30 p.m. equator-crossing time). The daily biomass burning $\mathrm{CO}$ emission rate is then simply approximated as the 
product of monthly $\mathrm{CO}$ emission and the ratio between daily and monthly fire counts for each grid.

\subsection{Plume-rise parameterization scheme}

The plume-rise parameterization scheme was originally developed by Latham (1994) and implemented into a regional forecast model by Freitas et al. (2006, 2007a). The vertical transport of hot gases and particles emitted from biomass burning in low resolution atmospheric-chemistry transport models is simulated by embedding a 1-D cloud-resolving model with appropriate lower boundary conditions in each column of the 3-D host model. MODIS/Terra fire counts provide the fire location, and land use datasets are used to characterize the fire properties. The CAM model provides the environmental conditions and, finally, the plume-rise is explicitly simulated. The lower and upper limits of the final rise of the plume are then used in the fire-related emissions field of the CAM model to determine the vertical injection range during the flaming phase for each time step.

Land-cover data were derived from the MODIS land-cover product at $1 \mathrm{~km}$ resolution. The primary land-cover types in this product are 17 land cover classes following the International Geosphere Biosphere Programme (IGBP) scheme. We adopted the approach of Freitas et al. (2007a) to aggregate the classes into three major vegetation types: forest, savanna and grassland. The minimum (maximum) heat fluxes for forest, savanna, and grassland fires are 30.0 (80.0), 4.4 (23), and $3.3(3.3) \mathrm{kW} \mathrm{m}^{-2}$, respectively. Fire size affects the plumerise height through decreasing the role of entrainment. In the 1-D plume model, the entrainment coefficient is inversely proportional to fire size. Similar to the work in Freitas et al. (2005), a constant fire size (20 ha) was used in this study. Preliminary test simulations, using fire sizes of 10, 20, and 40 ha have shown that the patterns and magnitudes of simulated biomass plumes are very similar. The existence of a diurnal cycle of fire activity has been established through both ground-based observations and satellite data (Prins and Menzel, 1992; Langaas, 1993; Prins et al., 1998; Eva and Lambin, 1998; Pack et al., 2000; Justice et al., 2002). Following Freitas et al. (2005), the diel cycle of emissions is defined by a Gaussian function with a peak value in the local afternoon (01:45 p.m.) and width of $8 \mathrm{~h}$. The peak time is consistent with that typically observed by Tropical Rainfall Measuring Mission (TRMM) Visible and Infrared Scanner (VIRS) (Giglio et al., 2003).

\section{Evaluation of CAM simulation}

The CAM simulation was evaluated using ground-based, aircraft, and MOPITT satellite measurements made during SAFARI 2000. The corresponding locations of ground-based and airborne $\mathrm{CO}$ measurements are displayed in Fig. 1.

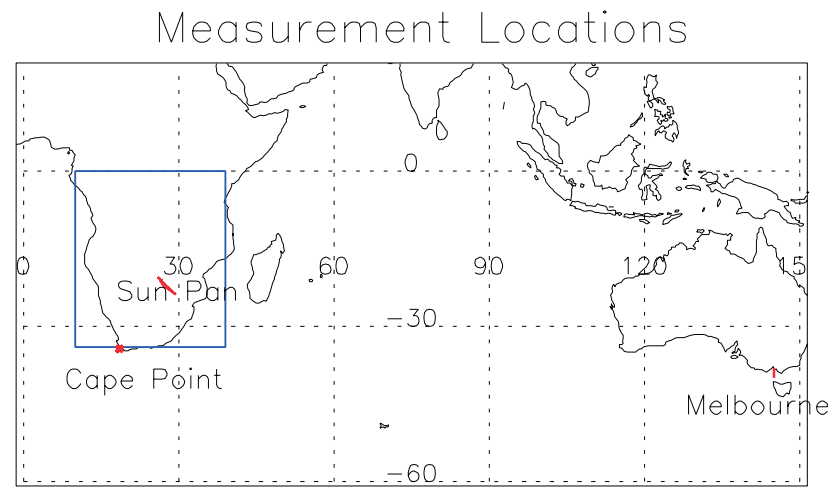

Fig. 1. Ground-based station (red star) and aircraft flight tracks for CO measurements (red lines). Blue rectangle, used in Sect. 4.3, marks the Southern Africa region with latitude from $35^{\circ} \mathrm{S}$ to $0^{\circ}$ and longitude from $10^{\circ} \mathrm{E}$ to $40^{\circ} \mathrm{E}$.

\subsection{Evaluation with MOPITT CO measurements}

The MOPITT instrument, onboard EOS/Terra, makes nadir observations of $\mathrm{CO}$. The $\mathrm{CO}$ mixing ratios are retrieved for 7 pressure levels from the surface to $150 \mathrm{hPa}$ with the highest sensitivity at $700 \mathrm{hPa}$ and a $10 \%$ precision (Deeter et al., 2003; Li et al., 2005). Here we focus on the comparison between the model and MOPITT Level 3 (L3) CO at $700 \mathrm{hPa}$. The MOPITT L3 data product used here is the daily mean gridded version of the daily L2 CO profile. Retrievals are performed using the optimal estimation technique (Pan et al., 1998; Edwards et al., 1999). To make a proper comparison between the MOPITT retrievals with the CAM simulation, the modeled $\mathrm{CO}$ profile $(x)$ must be transformed using the MOPITT a priori CO profile $(a)$ and averaging kernel matrix (A). The retrieved $\mathrm{CO}\left(x^{\prime}\right)$ profiles can be approximated as:

$x^{\prime}=a+\mathbf{A}(x-a)$.

A single a priori profile is used for the $\mathrm{L} 2$ retrieval (Deeter et al., 2003), while the averaging kernel depends on the temperature profile, surface temperature, and surface emissivity, and is thus a function of temporal and spatial coordinates. The model output was sampled at the location of each MOPITT profile, then the L2 averaging kernels and a priori applied to individual model profiles, and finally, the results were averaged over the 3 days and each $1^{\circ} \times 1^{\circ}$ grid cell. The mean transformed CO concentrations during 10 12 September 2000 at $696 \mathrm{hPa}$ for the simulations with and without the plume-rise parameterization are compared with the corresponding MOPITT 3-day composite $\mathrm{CO}$ at $700 \mathrm{hPa}$. For the simulation without the plume-rise parameterization, biomass burning emissions are assumed to take place in the lowest model-layer. The general patterns in $\mathrm{CO}$ concentration are strikingly consistent among the simulations and satellite measurements. Elevated CO concentrations are seen over the biomass burning source regions (Southern Africa 
a. $\mathrm{CO}(\mathrm{ppb})$ at $696 \mathrm{hPa}$ MOPITT Sept. $10-12,2000$

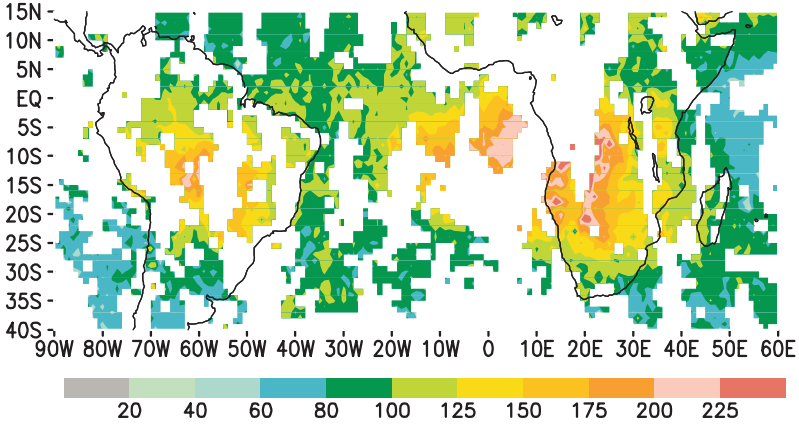

b. $\mathrm{CO}(\mathrm{ppb})$ at $696 \mathrm{hPa}$ model-NPR Sept. 10-12,2000

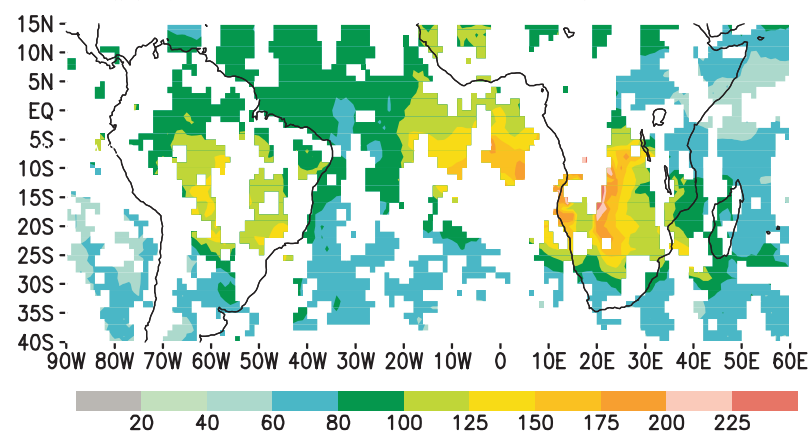

c. $\mathrm{CO}(\mathrm{ppb})$ at $696 \mathrm{hPa}$ model-PR Sept. 10-12,2000

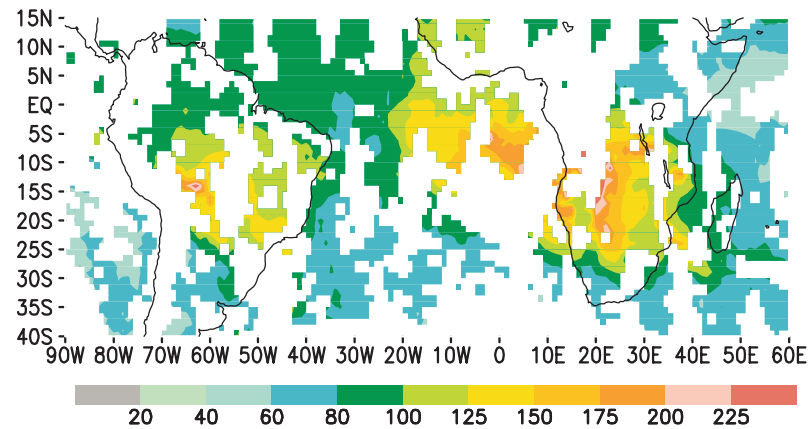

Fig. 2. Mean concentrations (ppb) of $\mathrm{CO}$ at $700 \mathrm{hPa}$ observed by MOPITT on 10-12 September 2000 (a) and model values at $700 \mathrm{hPa}$ for the NPR simulation (b) and PR simulation (c). White areas indicate regions where the MOPITT observations are obscured by clouds.

and South America). Both the simulations and MOPITT measurements also show high $\mathrm{CO}$ values over the Southern Atlantic Ocean. Similar with other model/MOPITT CO comparison work (Allen et al., 2004; Arellano et al., 2006), the model generally has lower CO concentration than MOPITT measurements. It is also evident that the agreement between the modeled and MOPITT CO is slightly improved when the plume-rise subgrid mechanism is included.

To compare quantitatively the model and MOPITT CO, scatter plots of the two datasets within the domain of Fig. 2 for the no plume-rise (NPR) and plume-rise (PR) simula-
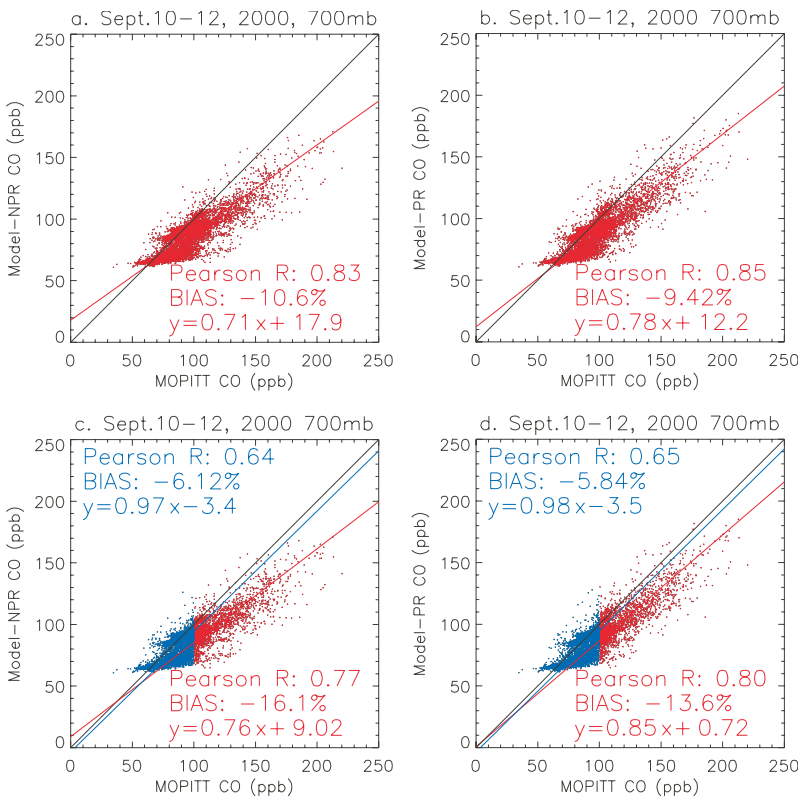

Fig. 3. Scatter plots of modeled versus MOPITT CO at $700 \mathrm{hPa}$ on 10-12 September 2000 within the Fig. 2 domain for the NPR (a and $\mathbf{c}$ ) and PR (b and d) simulations. The black lines represent a $1: 1$ correlation. The red lines for $a$ and $b$ are the linear regression for CO data. The red and blue lines for $\mathrm{c}$ and $\mathrm{d}$ represent the linear regression for higher $(>100 \mathrm{ppb})$ and lower $(<100 \mathrm{ppb})$ MOPITT $\mathrm{CO}$ data, respectively. The Pearson correlation coefficients $R$, mean biases, and regression equations are indicated.

tions are depicted in Fig. 3a and b, respectively. There is a strong correlation between the model and MOPITT CO. The correlation coefficients $(R)$ for the NPR and PR simulations are 0.83 and 0.85 , respectively. The model tends to underestimate MOPITT CO (i.e negative mean bias). The mean biases for the NPR and PR simulations are $-10.6 \%$ and $-9.42 \%$, respectively. The negative biases for the dataset with higher MOPITT CO mixing ratio (red color in Fig. 3c and d) $(-16.11 \%$ and $-13.6 \%)$ are significantly larger than those with lower MOPITT CO mixing ratio (blue color in Fig. $3 c$ and d) $(-6.12 \%$ and $-5.84 \%)$, implying that simulation of $\mathrm{CO}$ mixing ratio within or near source regions is particularly difficult. When the plume-rise scheme is included, the detectable improvement in $\mathrm{CO}$ forecast mainly occurs in the dataset with higher MOPITT CO mixing ratios, with mean bias reduced from $-16.1 \%$ to $-13.6 \%$. Additionally, the correlation coefficient increased from 0.77 to 0.80 , the slope of regression line increased from 0.76 to 0.85 , and y-intercept decreased from 9.02 to 0.72 . As the results indicate, the plume-rise parameterization does not completely resolve the difference between the retrieved model and $\mathrm{MO}$ PITT CO at $700 \mathrm{hPa}$ level.

The discrepancy between the modeled and MOPITT measured CO may be partly due to the coarse model resolution 


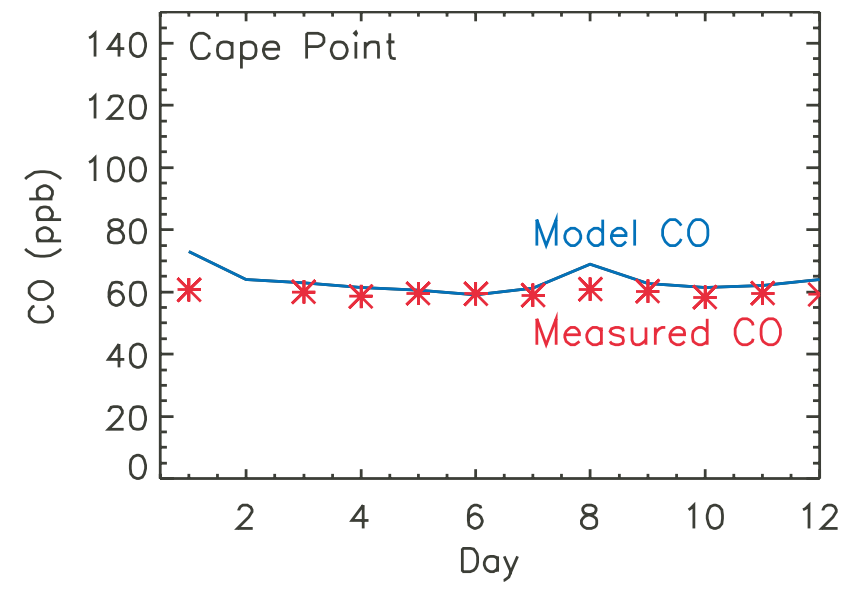

Fig. 4. Daily surface concentrations (ppb) of measured (red) and modeled CO (blue) over Cape Point, South Africa $\left(34.4^{\circ} \mathrm{S}, 18.5^{\circ} \mathrm{E}\right)$ from 1 September 2000 to 12 September 2000.

$\left(2^{\circ} \times 2.5^{\circ}\right)$. Use of inaccurate emissions is another possible reason. The modeled day-to-day variation of biomass burning emission depends on the MODIS fire count data. The presence of cloud cover with only two MODIS/Terra observations per day often allowed missing detections of fires most active in the afternoon, possibly contributing to emission error. Furthermore, omission of the contribution of NMHCs and the use of inconsistent $\mathrm{OH}$ and $\mathrm{CO}$ emission data may also be considered as error sources. Only small effects are expected.

\subsection{Evaluation with ground measurement at Cape Point}

The ground-based $\mathrm{CO}$ measurements were obtained at Cape Point, South Africa $\left(34.4^{\circ} \mathrm{S}, 18.5^{\circ} \mathrm{E}\right)$ through the world Data Center for Greenhouse Gases (WDCGG, http://gaw.kishou. go.jp/wdcgg.html). Daily average surface CO mixing ratios at Cape Point for 1-12 September 2000 were compared to daily modeled surface mixing ratios for the NPR simulation (Fig. 4). The model CO matches the observed CO for most of the simulated days well. The averaged absolute difference is only $6.4 \%$. Cape Point samples the Southern Ocean more effectively than other Southern Africa sites. The good agreement between the model and ground measurement at Cape Point implies that the simple formulations of the model can simulate the background $\mathrm{CO}$. The comparison between the PR and NPR simulations (not shown) show the plume-rise process has a negligible effect on the background $\mathrm{CO}$.

\subsection{Evaluation with aircraft measurements}

During the SAFARI 2000 dry season airborne campaign, two South African Weather Bureau Aerocommander aircraft (JRA and JRB) extensively sampled smoke plumes over Southern Africa (Piketh et al., 2004). In association with the SAFARI 2000 Dry Season Campaign in Africa,

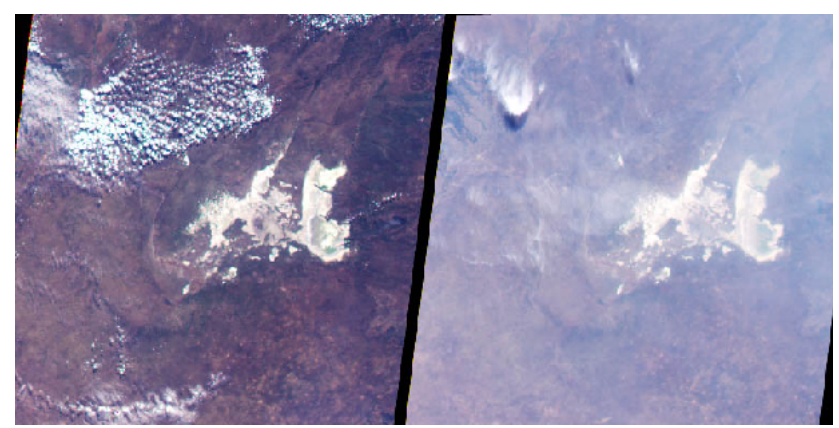

Fig. 5. MISR images of Sun Pan, Botswana $\left(20.53^{\circ} \mathrm{S}, 26.07^{\circ} \mathrm{E}\right)$ on 18 August (left panel) and 3 September (right panel) 2000.

the Commonwealth Scientific and Industrial Research Organization (CSIRO) division of Atmospheric Research conducted aircraft measurements downwind over Australia. The coordinated aircraft measurements provide an opportunity to check the model performance in simulating long-range transport of $\mathrm{CO}$. To assess the model's ability to simulate $\mathrm{CO}$ concentrations and identify the effects of plume-rise processes on short and long-range $\mathrm{CO}$ transports, we compared the model $\mathrm{CO}$ with the aircraft measurements for 3 and 13 September near the biomass burning source (South Africa and Botswana) and far downwind (Melbourne, Australia) areas, respectively. A previous study (Chatfield et al., 2002) shows that the high temporal and spatial variations of plumes and relatively low spatial coverage of flight tracks make point-to-point comparison unrealistic. Therefore, in this study, we focus on the comparison over the flight domains during the aircraft sampling period. Specifically, we look at whether, within the vicinity of the flights, the model is capable of predicting plumes with similar mixing ratios and distributions. Figure 5 shows the MISR (the Multiangle Imaging Spectro-Radiometer) images of Sun Pan, Botswana $\left(20.53^{\circ} \mathrm{S}, 26.07^{\circ} \mathrm{E}\right)$ on 18 August and 3 September 2000, respectively. It is apparent that wild and manmade grass fires that erupted earlier at several spots near the pan increased haziness on 3 September (Abdou et al., 2006). The CO vertical profiles around Sun Pan, Botswana (20-24 ${ }^{\circ} \mathrm{S}$ and 24 $30^{\circ}$ E) for 3 September 2000 between the model simulations and aircraft observations are compared in Fig. 6. The observed CO displays less variation with altitude. The averaged $\mathrm{CO}$ is close to $350 \mathrm{ppb}$ through all levels. The simulation without the plume-rise process fails to reproduce the observed vertical distribution and magnitudes. The biomass burning emissions are not effectively transported to the middle troposphere, consequently, the $\mathrm{CO}$ mixing ratios near the surface (at upper-level) are significantly higher (lower) than measurements. Better agreement between the modeled and aircraft-measured $\mathrm{CO}$ is obtained for the PR simulation. As demonstrated in the regional model simulation over South America (Freitas et al., 2006), the plume-rise mechanism 


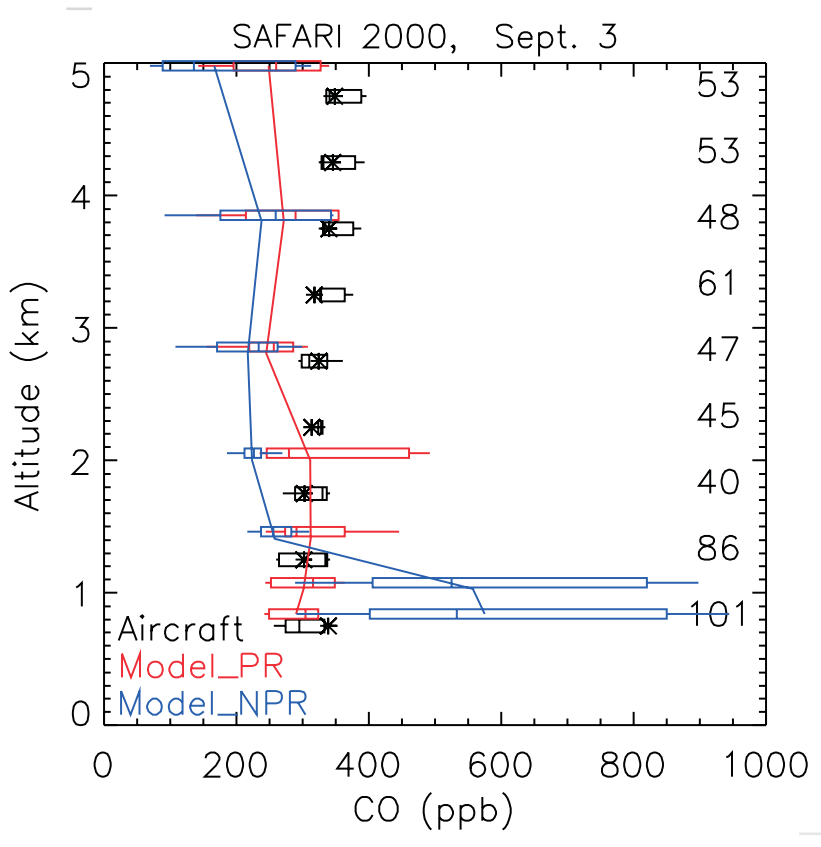

Fig. 6. CO vertical profiles averaged over $20-24^{\circ} \mathrm{S}$ and $24-30^{\circ} \mathrm{E}$ for 3 September 2000 from the model (red and blue lines) and South African aircraft measurement (black stars). The 25, 50, and 75 percentiles of the measured and simulated $\mathrm{CO}(\mathrm{ppb})$ are denoted by the vertical bars. The horizontal lines indicate the ranges. The aircraft measurements are averaged over a $500 \mathrm{~m}$ height range. The numbers of observations in each height range are indicated.

tends to loft more $\mathrm{CO}$ to the middle troposphere. For the PR simulation, the simulated $\mathrm{CO}$ at lower levels $(1 \mathrm{~km}-3 \mathrm{~km})$ is closer to the observation than upper levels $(3 \mathrm{~km}-5 \mathrm{~km})$. It should also be mentioned that the accuracy of aircraft measurements above $3 \mathrm{~km}$ are less reliable (personal communication with D. Stein, 2006).

Compared to the effects of the plume-rise mechanism on the source region or short-range transport, the effect on longrange transport is small. Figure 7 shows the observed and simulated CO around Melbourne, Australia for 5 and 13 September, representing local background and polluted days, respectively. As noted in Sinha et al. (2004), the elevated $\mathrm{CO}$ (approximately $20 \mathrm{ppb}$ higher than background values) over Melbourne, for 13 September is mainly due to longrange transport (more than $10000 \mathrm{~km}$ ) from Southern Africa and South America. Both the PR and NPR simulations are comparable with the observations for the clear and polluted atmosphere over Melbourne. The simulations capture the observed increase of $\mathrm{CO}$ mixing ratio with altitude for 13 September, and the relative uniform vertical distribution for 5 September. The CO mixing ratio for 13 September is slightly higher for the PR simulation with a maximum enhancement of 6-7 ppb at $5 \mathrm{~km}$, significantly lower than that for the shortrange transport case ( $87 \mathrm{ppb}$ at $2 \mathrm{~km}$ on 3 September). The smaller effect of plume-rise on $\mathrm{CO}$ mixing ratio for long-

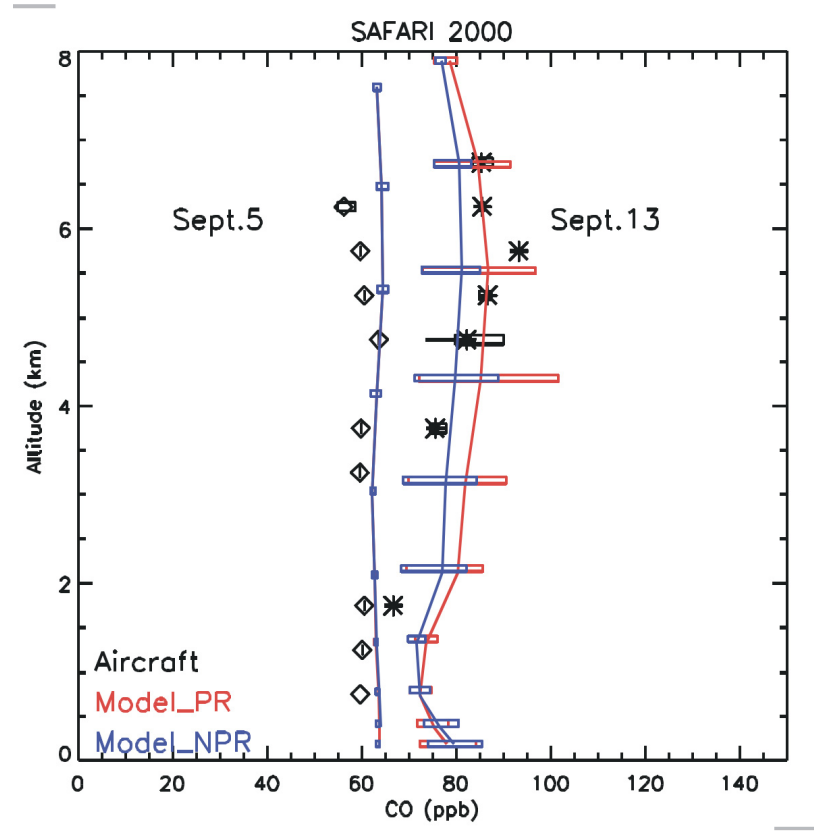

Fig. 7. CO vertical profiles averaged over $36-42^{\circ} \mathrm{S}$ and $142-148^{\circ} \mathrm{E}$ from the model (red and blue lines) and aircraft measurements near Melbourne, Australia for 5 and 13 September 2000. Black diamonds and stars represent measurements for 5 and 13 September 2000 , respectively. The 25,50 , and 75 percentiles of the measured and simulated $\mathrm{CO}(\mathrm{ppb})$ are denoted by the vertical bars. The horizontal lines indicate the ranges. The aircraft measurements are averaged over a $500 \mathrm{~m}$ height range.

range transport could be explained by greater mixing with clean background atmosphere. In other words, the enhancement is spread over a large volume with time.

\section{The effect of plume-rise mechanism on the $\mathrm{CO}$ export and $\mathrm{CO}$ budget}

During Southern Africa's dry spring season from July through October, a large amount of $\mathrm{CO}$ from African fires is transported to the Southern Atlantic and Indian Oceans. The 13-day simulation in this study covers the $\mathrm{CO}$ export from Southern Africa northwestward to the Atlantic and southeastward to the Indian Ocean. For the period 3-7 September, the fire that raged across Southern Africa produced a thick biomass plume that was transported towards the southwest across Botswana and South Africa and ultimately to the Indian Ocean. This phenomenon has been designated the "River of Smoke". However, for 8-13 September, the "Great African Plume" (Chatfield et al., 1998) was directly transported westward in a latitude band between $15^{\circ} \mathrm{S}$ and $0^{\circ}$ to the Equatorial Atlantic Ocean (see Fig. 8). 

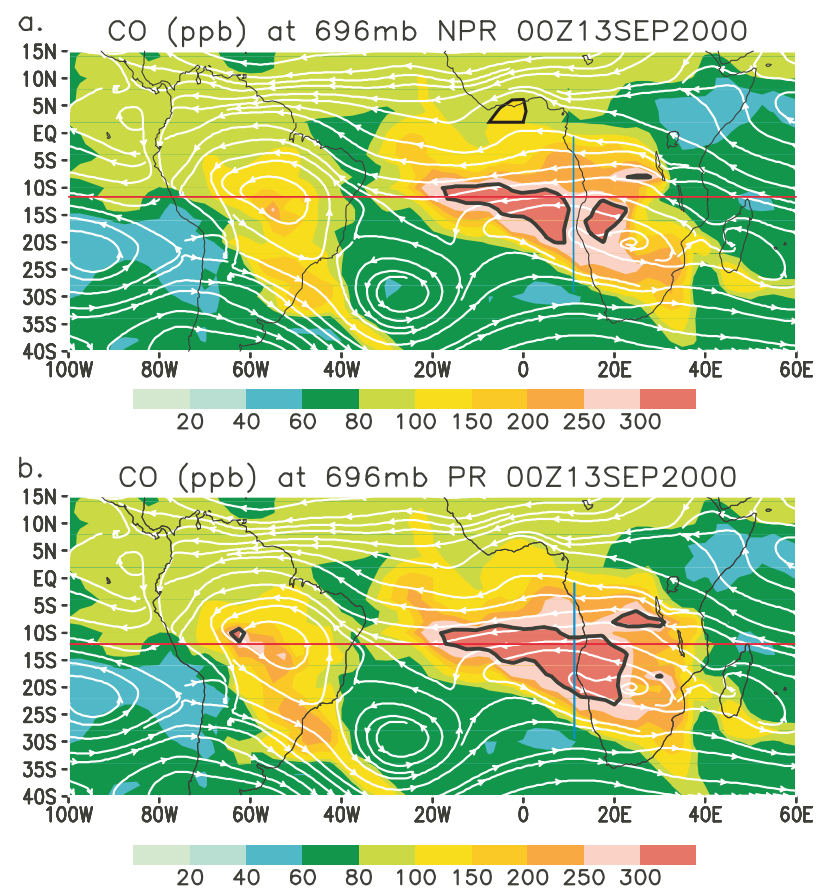

Fig. 8. Simulated CO concentrations for (a) the NPR simulation and (b) the PR simulation at $696 \mathrm{hPa}$ on 13 September 2000. Three-day (10-12 September 2000) averaged streamlines in white are superimposed. Red and blue reference lines, used in Figs. 9 and 10, are shown in this figure. Thick black line is the $300 \mathrm{ppb}$ contour.

4.1 The effect of the plume-rise mechanism on the $\mathrm{CO}$ export to the Atlantic Ocean

To estimate the effects of plume-rise on the $\mathrm{CO}$ export from Southern Africa to the Southern Atlantic Ocean, we display the modeled CO concentrations (Fig. 8) for the simulations with and without the plume-rise mechanism for 13 September 2000 at $696 \mathrm{hPa}$ when the "Great Africa Plume" flowed into the Southern Atlantic Ocean. In the simulation with the plume-rise scheme, the region over Southern Africa and the Southern Atlantic Ocean with a CO mixing ratio greater than $300 \mathrm{ppb}$ is much larger than that without the plume-rise scheme. The ratio of the area where the $\mathrm{CO}$ mixing ratio exceeds $300 \mathrm{ppb}$ between two simulations is 1.81 . Both near and distant concentrations are enhanced due to greater lofting to the lower-middle troposphere.

Figure 9a, b, and c show the vertical cross sections of $\mathrm{CO}$ concentrations for the NPR and PR simulations and the concentration difference along the red reference lines in Fig. 8. Both of the NPR and PR simulations show that CO can be lofted to higher altitudes ( $\sim 200 \mathrm{hPa}$ ) over South America due to prevailing deep convection. In contrast, biomass-burning plumes over Southern Africa seldom reach the higher troposphere because during the austral spring season, anticyclonic flow is dominant over the Southern African subcontinent and injection height is determined by large scale motion, verti-

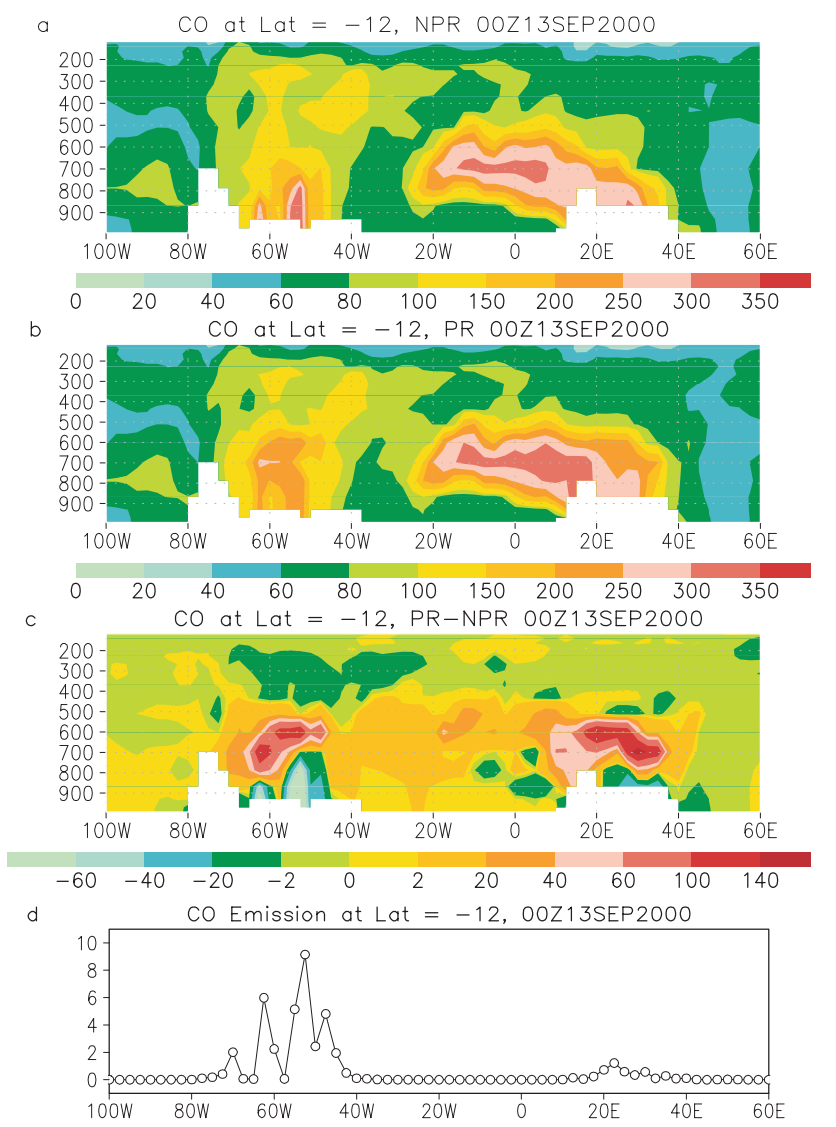

Fig. 9. Vertical cross sections of $\mathrm{CO}(\mathrm{ppb})$ along the red reference lines in Fig. 8 for the NPR simulation (a), PR simulation (b), and the concentration difference between PR and NPR simulations (c). (d) Corresponding $\mathrm{CO}$ emission rate $\left(\mathrm{kg} \mathrm{s}^{-1}\right)$. White areas indicate topography.

cal mixing, and plume-rise mechanisms. Significant $\mathrm{CO}$ enhancement by the plume-rise process is mainly located in the lower middle troposphere over the biomass source regions (Southern Africa and South America) and downwind of Southern Africa. The maximum enhancements for Southern Africa and South America are more than $140 \mathrm{ppb}$ and $100 \mathrm{ppb}$, respectively. Plume tops are also higher in the PR simulation than those in the NPR simulation over the biomass source regions. For example, the plume top $(>150 \mathrm{ppb})$ at $27^{\circ} \mathrm{E}$ is $700 \mathrm{hPa}$ for the NPR simulation, while the corresponding altitude for the $\mathrm{PR}$ simulation can reach to $550 \mathrm{hPa}$ level. A similar situation can also be noted over South America. Since more CO is lofted to the lower-middle troposphere for the PR simulation, significant reduction in CO concentration occurs at the lower troposphere near the biomassburning source areas. The $\mathrm{CO}$ reduction distribution in the lower troposphere is closely related to the biomass burning emission distribution (Fig. 9d).

A smaller CO reduction (less than $20 \mathrm{ppb}$ ) is also detected in the upper troposphere $(200-500 \mathrm{hPa})$ over South America 
a. $\quad$ CO FLUX $(\mathrm{kg} / \mathrm{s})$ 1OE NPR OOZ13SEP2000

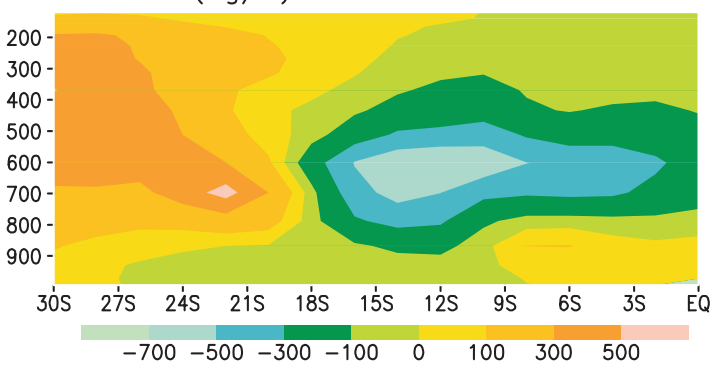

b. CO FLUX (kg/s) 10E PR OOZ13SEP2000

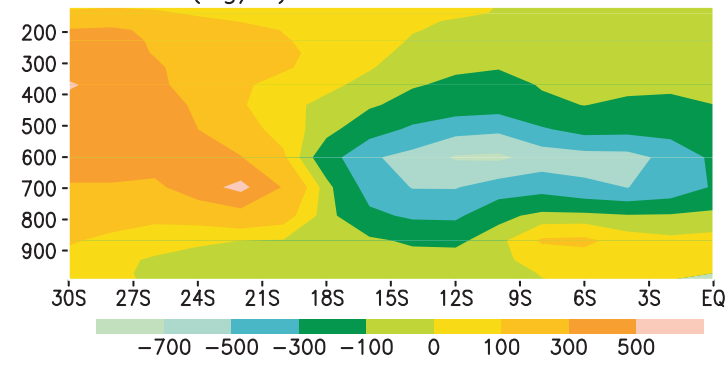

c. CO FLUX Difference (kg/s) 10E OOZ13SEP2000

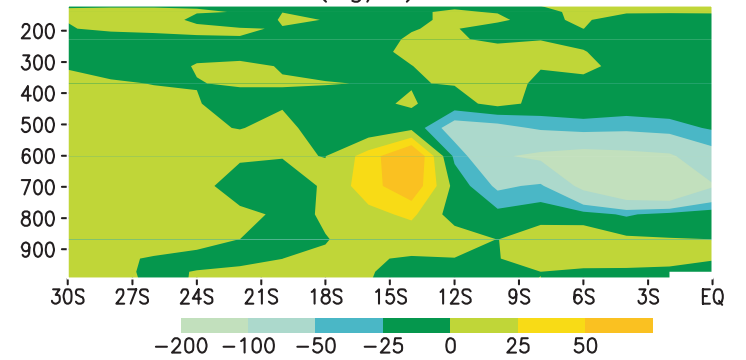

Fig. 10. Vertical cross sections of zonal CO flux $\left(\mathrm{kg} \mathrm{s}^{-1}\right)$ over each latitude-altitude grid along the blue reference lines in Fig. 8 for the NPR simulation (a), PR simulation (b), and the corresponding difference between the PR and NPR simulations (c).

(Fig. 9c), and it should be linked to deep convection process. Deep convection draws mostly from the boundary layer. The $\mathrm{CO}$ depletion by plume-rise process in the lower troposphere leads to less CO lofting by deep convection process.

The vertical cross sections of CO flux for the NPR (Fig. 10a) and PR simulations (Fig. 10b), sampled along the blue reference lines $\left(10^{\circ} \mathrm{E}\right)$ in Fig. 8, more clearly indicate the effect of the plume-rise on $\mathrm{CO}$ export. As with the simulations in Sinha et al. (2004), the westward (eastward) flux prevailed over the $0-18^{\circ} \mathrm{S}\left(18-30^{\circ} \mathrm{S}\right)$ latitude band. An evident feature, the westward flux core, is stronger for the PR simulation than the NPR simulation. The maximum difference between the PR and NPR simulations (Fig. 10c) is $127 \mathrm{~kg} \mathrm{~s}^{-1}$ or $28 \%$ at $3^{\circ} \mathrm{S}$ and $650 \mathrm{hPa}$. The larger westward flux of CO for the PR simulation leads to the extra CO exported to the higher middle troposphere in the Southern Atlantic Ocean.
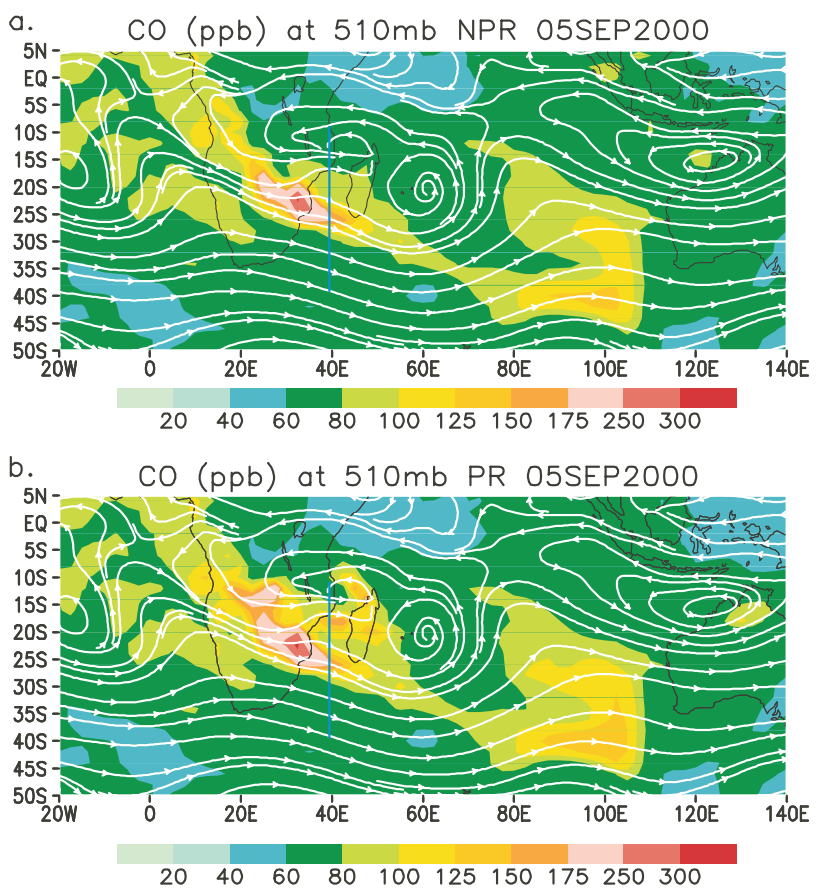

Fig. 11. Simulated CO concentrations for (a) the NPR simulation and (b) the PR simulation at $510 \mathrm{hPa}$ on 5 September, 2000. Threeday (3-5 September 2000) averaged streamlines in white are superimposed. The blue reference lines, used in Fig. 12, are drawn.

4.2 The effect of the plume-rise mechanism on the $\mathrm{CO}$ export to the Indian Ocean

Figure 11 shows the $\mathrm{CO}$ concentration at $510 \mathrm{hPa}$ for the NPR simulation and PR simulation on 5 September 2000. Again the PR simulation produces more CO than the NPR simulation over both the source region and remote East Indian Ocean during the River of Smoke. In addition, biomass $\mathrm{CO}$ from Africa fires was transported to Northern Madagascar in the PR simulation which does not appear in the NPR simulation, implying an impact of the plume-rise mechanism on the horizontal transport pattern. The plume-rise parameterization also leads to a denser smoke plume over the eastern Indian Ocean. The area with a CO concentration larger than $125 \mathrm{ppb}$ is substantially larger in the PR simulation. Figure 12 displays the zonal CO flux for the NPR simulation, PR simulation, and $\mathrm{CO}$ flux difference along the eastern coast of Southern Africa $\left(40^{\circ} \mathrm{E}\right)$ for 5 September 2000 . The large eastward flux near $30^{\circ} \mathrm{S}$ between 600 and $750 \mathrm{hPa}$ (Fig. 12a and $b$ ) characterized the river of smoke event (Sinha et al., 2004). Another small eastward flux core near $16^{\circ} \mathrm{S}$ between 500 and $700 \mathrm{hPa}$ is embedded in the westward flux band. The two eastward flux cores are stronger in the PR simulation than the NPR simulation (Fig. 12c). The maximum enhancement of the eastward flux near $30^{\circ} \mathrm{S}$ reaches $88 \mathrm{~kg} \mathrm{~s}^{-1}$ (20\%), which is similar to the maximum enhancement of the 


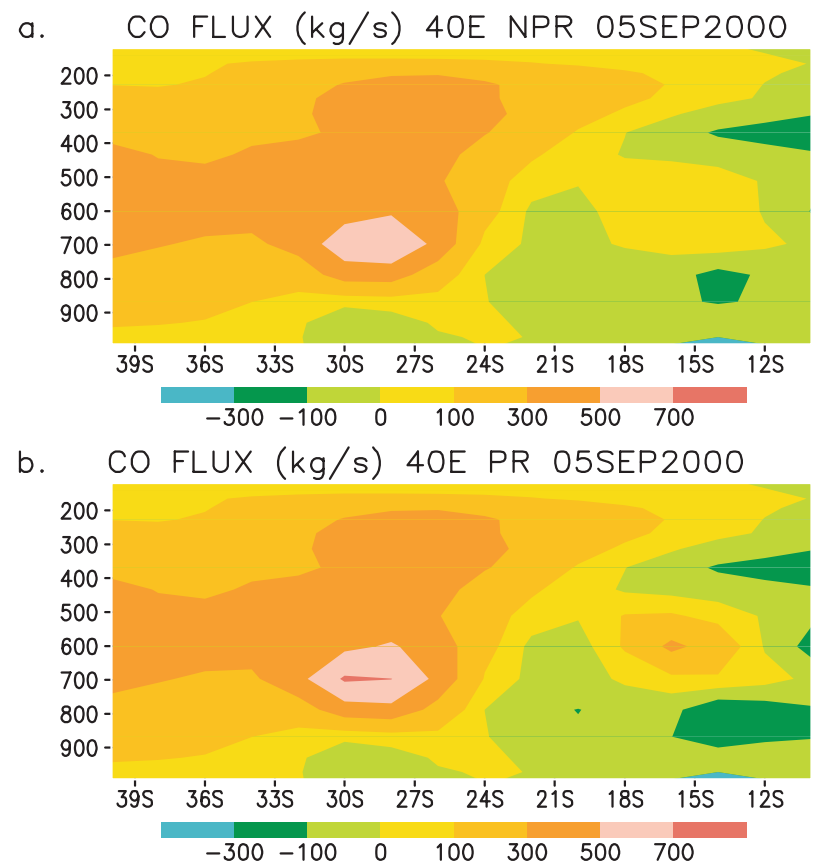

c. CO FLUX Difference (kg/s) 40E 05SEP2000

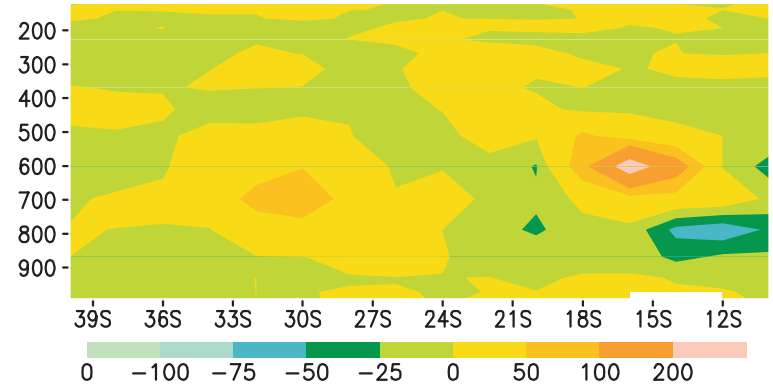

Fig. 12. Vertical cross sections of zonal CO flux $\left(\mathrm{kg} \mathrm{s}^{-1}\right)$ over each latitude-altitude grid along the blue reference lines in Fig. 11 for the NPR simulation (a), PR simulation (b), and the corresponding difference between the PR and NPR simulations (c).

westward export to the Atlantic Ocean (28\%) (see Sect. 4.1). To a greater degree, the corresponding enhancement near $16^{\circ} \mathrm{S}$ reaches $200 \mathrm{~kg} \mathrm{~s}^{-1}$ (over $240 \%$ ). The reason for the larger enhancement is that the biomass $\mathrm{CO}$ was lofted to a higher altitude $(\sim 510 \mathrm{hPa})$ at the source region where the prevailing westerlies further transported $\mathrm{CO}$ to the Indian Ocean and Northern Madagascar in the PR simulation.

\subsection{Budget analysis of CO over Southern Africa}

Atmospheric $\mathrm{CO}$ concentrations and distributions are affected by chemical, emission, and transport processes. The 13-day budget of atmospheric CO over Southern Africa is analyzed in Table 1 . The region is marked by the blue rectangle in Fig. 1. The budget calculations for the NPR simulation indicate that the surface emission $(13.72 \mathrm{Tg})$ is the largest source of $\mathrm{CO}$, which is more than one-order larger
Table 1. Thirteen-day budget of atmospheric CO $(\mathrm{Tg})$ over Southern Africa in CAM.

\begin{tabular}{lrr}
\hline Process & NPR & PR \\
\hline Emissions & 13.72 & 13.72 \\
3-D production (by $\mathrm{CH}_{4}$ and $\left.\mathrm{OH}\right)$ & 1.05 & 1.05 \\
3-D loss (oxidation by $\mathrm{OH}$ ) & 3.94 & 3.88 \\
Transport to the east (east section) & 10.25 & 10.24 \\
Transport to the south (south section) & 2.99 & 2.96 \\
Transport from the west (west section) & 8.92 & 8.79 \\
Transport to the north (north section) & 2.80 & 2.82 \\
Net outflow & 7.12 & 7.23 \\
Initial burden & 13.97 & 13.97 \\
Final burden & 17.45 & 17.41 \\
Increased burden & & \\
(Final burden - initial burden) & 3.48 & 3.44 \\
\hline
\end{tabular}

than the 3-D production $(1.05 \mathrm{Tg})$. About half of the emission $(7.12 \mathrm{Tg})$ is transported out of the subcontinent. The 3-D loss $(3.94 \mathrm{Tg})$ is comparable to the increased burden $(3.48 \mathrm{Tg})$ due to all processes. The increase in burden of $\mathrm{CO}$ within the analysis region is consistent with the general increase in $\mathrm{CO}$ emissions as reflected in the MOPITT averages for August and September, 2000. Both South American and Central/Southern African concentrations increase in these analyses.

The budget comparison between the NPR and PR simulations shows the plume-rise process does not have important impact on the $\mathrm{CO}$ budget of the entire atmospheric column over Southern Africa (Table 1). However, the plumerise does increase (decrease) the increased burden above (below) the 744-hpa level by nearly $0.60 \mathrm{Tg}$ (Table 2), which accounts for about $35 \%$ of the increased regional burden in both layers. The decreased (increased) amount is also comparable to (50\% more than) the chemical production by $\mathrm{OH}$ and $\mathrm{CH}_{4}$ in lower (upper) layers. $\mathrm{CO}$ has a longer lifetime in the upper atmosphere than the lower atmosphere due to a lower reaction rate and $\mathrm{OH}$ concentration. This redistribution of CO may have important impacts on the regional chemical composition.

Table 2 also shows an enhanced eastward transport of $\mathrm{CO}$ in the PR simulation through the upper east section, which is consistent with the finding in Figs. 11 and 12. Upper and lower transport regions are separated by the $744 \mathrm{hPa}$ level. This increased outflow $(0.07 \mathrm{Tg})$ through the upper east section approximately equals to the decreased outflow $(0.08 \mathrm{Tg})$ through the lower east section. This leads to a small difference in the total transport to the east $(0.01 \mathrm{Tg})$ between the NPR and PR simulations. In a similar way, the plume-rise process also leads to a weakening outflow (smaller transport from the west) through the lower west section. The increased outflow (smaller transport from the east) $(0.25 \mathrm{Tg})$ through the upper west section in the PR simulation is partially offset by the decreased outflow $(0.12 \mathrm{Tg})$ through the lower west 
Table 2. Thirteen-day budget of lower and upper atmospheric CO (Tg) over Southern Africa in CAM.

\begin{tabular}{|c|c|c|}
\hline \multicolumn{3}{|l|}{ Lower Atmosphere (below $744 \mathrm{hPa}$ ) } \\
\hline Process & NPR & PR \\
\hline 3-D production (by $\mathrm{CH}_{4}$ and $\mathrm{OH}$ ) & 0.64 & 0.64 \\
\hline 3-D loss (oxidation by $\mathrm{OH}$ ) & 2.27 & 2.12 \\
\hline Transport to the east (east section) & 0.41 & 0.33 \\
\hline Transport to the south (south section) & 1.54 & 1.49 \\
\hline Transport from the west (west section) & -3.54 & -3.42 \\
\hline Transport to the north (north section) & 1.73 & 1.75 \\
\hline Net outflow & 7.22 & 6.99 \\
\hline Initial burden & 5.09 & 5.09 \\
\hline Final burden & 6.82 & 6.25 \\
\hline $\begin{array}{l}\text { Increased burden } \\
\text { (Final burden - initial burden) }\end{array}$ & 1.73 & 1.15 \\
\hline \multicolumn{3}{|l|}{ Upper Atmosphere (above $744 \mathrm{hPa}$ ) } \\
\hline Process & NPR & PR \\
\hline 3-D production (by $\mathrm{CH}_{4}$ and $\mathrm{OH}$ ) & 0.41 & 0.41 \\
\hline 3-D loss (oxidation by $\mathrm{OH}$ ) & 1.67 & 1.76 \\
\hline Transport to the east (east section) & 9.84 & 9.91 \\
\hline Transport to the south (south section) & 1.45 & 1.47 \\
\hline Transport from the west (west section) & 12.45 & 12.21 \\
\hline Transport to the north (north section) & 1.07 & 1.07 \\
\hline Net outflow & -0.09 & 0.24 \\
\hline Initial burden & 8.88 & 8.88 \\
\hline Final burden & 10.57 & 11.16 \\
\hline $\begin{array}{l}\text { Increased burden } \\
\text { (Final burden - initial burden) }\end{array}$ & 1.69 & 2.28 \\
\hline
\end{tabular}

section, which induces a net difference of $0.13 \mathrm{Tg}$ between the two simulations. The increased outflow in the upper west section is mainly caused by the enhanced westward transport in the PR simulation during the Great African Plume event (see Figs. 9 and 10).

\section{Summary}

In this paper, we have used the NCAR CAM3 global model driven by assimilated meteorology during SAFARI 2000 to show how the plume-rise parameterization affects the CO transport over Southern Africa and export. Source-region comparisons with aircraft data suggest that the parameterization improves the distribution in $\mathrm{CO}$ with altitude and magnitude in Southern Africa as the regional model does in South America. The plume-rise scheme tends to loft more biomass burning $\mathrm{CO}$ into the lower-middle troposphere and leads to simulations of greater $\mathrm{CO}$ concentration in the upper atmosphere than the non-plume-rise. A budget calculation over Southern Africa suggests that the plume-rise process does not have important impacts on the $\mathrm{CO}$ production, loss, export, and burden over the entire atmospheric column. However, the plume-rise increases (decreases) the $\mathrm{CO}$ burden in the upper (lower) atmosphere. The increased (decreased) amount is comparable to the chemical production by $\mathrm{OH}$ and $\mathrm{CH}_{4}$ in the corresponding layers. Effective lofting by the plume-rise mechanism has important implications for local air quality forecast in areas affected by fire-related pollutants. In the presence of deep convection, the plume-rise parameterization decreases $\mathrm{CO}$ concentration in the upper troposphere. In terms of magnitude, the effect of the plume-rise mechanism on short-range transport is more significant than long-range transport during the simulation period due to $\mathrm{CO}$ dilution by clean background atmosphere.

The comparison between the model and MOPITT satellite $\mathrm{CO}$ indicates the CAM model can reasonably simulate the MOPITT CO patterns over South America, Southern Africa, and corresponding export during 10-12 September 2000 with a correlation coefficient of 0.85 for the PR simulation at $700 \mathrm{hPa}$ level. As found in other model/MOPITT comparison work, the CAM model tends to underestimate MOPITT CO by $\sim 10 \%$. The coarser model resolution, inaccurate emission data, missing contribution of NMHCs, and use of somewhat inconsistent $\mathrm{OH}$ and $\mathrm{CO}$ emission data could be potential reasons for the observed differences between the model and MOPITT CO.

Future work will focus on the effect of the plume-rise parameterization on fire-related carbonaceous aerosols. The goal is to improve the vertical distribution of aerosols, which is recognized as one of the biggest challenges for aerosol simulation (ICCP, 2000). The work will also include estimating the effect of the plume-rise mechanism on various fires in various geographic regions. The CALIPSO (Cloud-Aerosol Lidar and Infared Pathfinder Satellite Observations) spaceborne lidar provides unprecedented high resolution measurements of aerosol profiles on a global scale, and these will help to validate the modeled vertical distribution of aerosols.

Acknowledgements. We would like to acknowledge P. Rasch, P. Hess, and D. Bundy Coleman for kindly providing their utility program for mapping NCEP reanalysis data to FV grid. We are grateful to $\mathrm{G}$. Pétron for allowing us to use her $\mathrm{CO}$ emission data. We appreciate R. Namani and H. Hashimo for helping us to obtain MODIS land cover data. We thank NASA's tropospheric radiation program and Terra-Aqua validation program for supporting this research. The simulations under NASA HEC computing award SMD-07-0383 were performed on the Columbia supercomputer at NASA's Ames Research Center.

Edited by: I. Aben 


\section{References}

Allen, D., Pickering, K., and Fox-Rabinovitz, M.: Evaluation of pollutant outflow and $\mathrm{CO}$ sources during TRACEP using modelcalculated, aircraft-based, and Measurements of Pollution in the Troposphere (MOPITT)-derived CO concentrations, J. Geophys. Res., 109, D15S03, doi:10.1029/2003JD004250, 2004.

Abdou, W. A., Stuart, H., Pilorz, M. C., Helmlinger, M. C., Conel, J. E., Diner, D. J., Bruegge, C. J., and Martonchik, J. V.: Sua Pan surface Bidirectional Reflectance: A case study to evaluate the effect of atmospheric correction on the surface products of the Multi-angle Imaging SpectroRadiometer (MISR) during SAFARI 2000, IEEE T. Geosci. Remote, 44(7), 1699-1709, 2006.

Andreae, M. O.: Biomass burning. Its history, use, and distribution and its impact on environmental quality and global climate, in: Global Biomass Burning: Atmospheric, Climatic, and Biospheric Implications, edited by: Levine, J. S., MIT Press, Cambridge, Massachusetts, 3-21, 1991.

Arellano, Jr., A. F., Kasibhatla, P. S., Giglio, L., van der Werf, G. R., Randerson, J. T., and Collatz, G. J.: Timedependent inversion estimates of global biomass-burning $\mathrm{CO}$ emissions using Measurement of Pollution in the Troposphere (MOPITT) measurements, J. Geophys. Res., 111, D09303, doi:10.1029/2005JD006613, 2006.

Arellano, Jr., A. F., Raeder, K., Anderson, J. L., Hess, P. G., Emmons, L. K., Edwards, D. P., Pfister, G. G., Campos, T. L., and Sachse, G. W.: Evaluating model performance of an ensemblebased chemical data assimilation system during INTEX-B field mission, Atmos. Chem. Phys., 7, 5695-5710, 2007, http://www.atmos-chem-phys.net/7/5695/2007/.

Bey, I., Jacob, D. J., Logan, J. A., and Yantosca, R. M.: Asian chemical outflow to the Pacific in spring: Origins, pathways, and budgets, J. Geophys. Res., 106, 23 097-23 114, 2001.

Chatfield, R. B., Vastano, J. A., Li, L., Sachse, G. W., and Connors, V. S.: The Great African plume from biomass burning: Generalizations from a three-dimensional study of TRACE A carbon monoxide, J. Geophys. Res., 103, 28 059-28 078, 1998.

Chatfield, R. B., Guo, Z., Sachse, G. W., Blake, D. R., and Blake, N. J.: The subtropical global plume in the Pacific Exploratory MissionTropics A (PEMTropics A), PEMTropical B, and the Global Atmospheric Sampling Program (GASP): How tropical emissions affect the remote Pacific, J. Geophys. Res., 107(D16), 4278, doi:10.1029/2001JD000497, 2002.

Chin, Mian, Diehl, T., Ginoux, P., and Malm, W.: Intercontinental transport of pollution and dust aerosols: implications for regional air quality, Atmos. Chem. Phys., 7, 5501-5517, 2007, http://www.atmos-chem-phys.net/7/5501/2007/.

Crutzen, P. J., Heidt, L. E., Krasnec, J. P., Pollock, W. H., and Seiler, W.: Biomass burning as a source of atmospheric trace gases: $\mathrm{CO}, \mathrm{H}_{2}, \mathrm{~N}_{2} \mathrm{O}, \mathrm{NO}, \mathrm{CH}_{3} \mathrm{Cl}$, and $\mathrm{COS}$, Nature, 282, 30, 253-256, 1979.

Damoah, R., Spichtinger, N., Servranckx, R., Fromm, M., Eloranta, E. W., Razenkov, I. A., James, P., Shulski, M., Forster, C., and Stohl, A.: A case study of pyro-convection using transport model and remote sensing data, Atmos. Chem. Phys., 6, 173-185, 2006, http://www.atmos-chem-phys.net/6/173/2006/.

Deeter, M. N., Emmons, L. K., Francis, G. L., et al.: Operational carbon monoxide retrieval algorithm and selected results from the MOPITT instrument, J. Geophys. Res., 108, 4399, doi:10.029/2002JD003186, 2003.
Duncan, B. N., Strahan, S. E., Yoshida, Y., Steenrod, S. D., and Livesey, N.: Model study of the cross-tropopause transport of biomass burning pollution, Atmos. Chem. Phys., 7, 3713-3736, 2007,

http://www.atmos-chem-phys.net/7/3713/2007/.

Edwards, D. P., Halvorson, C. M., and Gille, J. C.: Radiative transfer modeling for the EOS Terra satellite Measurement of Pollution in the Troposphere (MOPITT) instrument, J. Geophys. Res., 104, 16755-16775, 1999.

Eva, H. and Lambin, E. F.: Remote sensing of biomass burning in tropical regions: Sampling issues and multisensor approach, Remote Sens. Environ., 64, 292-315, 1998.

Freitas, S. R., Longo, K. M., Silva Dias, M. A. F., Silva Dias, P. L., Chatfield, R., Prins, E., Artaxo, P., and Recuero, F. S.: Monitoring the transport of biomass burning emissions in South America, Environ. Fluid. Mech., doi:10.1007/s1065200502437, 5(12), 135-167, 2005.

Freitas, S. R., Longo, K. M., and Andreae, M. O.: Impact of including the plume rise of vegetation fires in numerical simulations of associated atmospheric pollutants, Geophys. Res. Lett., 33, L17808, doi:10.1029/2006GL026608, 2006.

Freitas, S. R., Longo, K. M., Chatfield, R., Latham, D., Silva Dias, M. A. F., Andreae, M. O., Prins, E., Santos, J. C., Gielow, R., and Carvalho Jr., J. A.: Including the sub-grid scale plume rise of vegetation fires in low resolution atmospheric transport models, Atmos. Chem. Phys., 7, 3385-3398, 2007a,

http://www.atmos-chem-phys.net/7/3385/2007/.

Freitas, S. R., Longo, K. M., Silva Dias, M. A. F., Chatfield, R., Silva Dias, P., Artaxo, P., Andreae, M. O., Grell, G., Rodrigues, L. F., Fazenda, A., and Panetta, J.: The Coupled Aerosol and Tracer Transport model to the Brazilian developments on the Regional Atmospheric Modeling System (CATT-BRAMS) - Part 1: Model description and evaluation, Atmos. Chem. Phys. Discuss., 7, 8525-8569, 2007b, http://www.atmos-chem-phys-discuss.net/7/8525/2007/.

Fromm, M., Alfred, J., Hoppel, K., Hornstein, J., Bevilacqua, R., Shettle, E., Servranckx, R., Li, Z., and Stocks, B.: Observations of boreal forest fire smoke in the stratosphere by POAM III, SAGE II, and lidar in 1998, Geophys. Res. Lett., 27, 14071410, 2000.

Giglio, L., Pinzon, J., and Kasibhatla, P.: Comment on Seasonal intraseasonal, and interannual variability of global land fires and their effects on atmospheric aerosol distribution, edited by: Ji Y. and Stocker E., J. Geophys. Res., 108(D24), 4754, doi:10.1029/2003JD003548, 2003.

Hao, W. M., Liu, M. H., and Crutzen, P. J.: Estimates of annual and regional releases of $\mathrm{CO}_{2}$ and trace gases to the atmosphere from fires in the tropics, based on the FAO statistics for the period 1975-1980, Fire in the Tropical Biota: Ecosystem Processes and Global Challenges, Ecol. Studies, 84, edited by: Goldammer, J. G., Springer-Verlag, New York, 440-462, 1990.

Holtslag, A. A. M. and Boville, B. A.: Local versus nonlocal boundarylayer diffusion in a global climate model, J. Climate, 6, 1825$1842,1993$.

Jost, H. J., Drdla, K., Stohl, A., Pfister, L., Loewenstein, M., Lopez, J. P., Hudson, P. K., Murphy, D. M., Cziczo, D. J., Fromm, M., Bui, T. P., DeanDay, J., Gerbig, C., Mahoney, M. J., Richard, E. C., Spichtinger, N., Pittman, J. V., Weinstock, E. M., Wilson, J. C., and Xueref, I.: In-situ observations of midlatitude forest 
fire plumes deep in the stratosphere, Geophys. Res. Lett., 31, L11101, doi:10.1029/2003GL019253, 2004.

Justice, C. O., Giglio, L., Korontzi, S., Owens, J., Morisette, J., Roy, D., Descloitres, J., Alleaume, S., Petitcolin, F., and Kaufman, Y.: The MODIS fire products, Remote Sens. Environ., 83(1-2), 244262, 2002.

Kalnay, E., Kanamitsu, M., Kistler, R., et al.: The NCEP/NCAR 40-year reanalysis project, B. Am. Meteorol. Soc., 77, 437-471, 1996.

Langaas, S.: A parameterised bispectral model for savanna fire detection using AVHRR night images, Int. J. Remote Sens., 14, 2245-2262, 1993.

Latham, D. J.: PLUMP: A onedimensional plume predictor and cloud model for fire and smoke managers, Research General Technical Report INTGTR314, Intermountain Research Station, November 1994.

Li, Q., Jiang, J. H., Wu, D. L., Read, W. G., Livesey, N. J., Waters, J. W., Zhang, Y., Wang, B., Filipiak, M. J., Davis, C. P., Turquety, S., Wu, S., Park, R. J., Yantosca, R. M., and Jacob, D. J.: Convective outflow of South Asian pollution: A global CTM simulation compared with EOS MLS observations, J. Geophys. Lett., 32, L14826, doi:10.1029/2005GL022762, 2005.

Lin, S. J.: A vertically Lagrangian finite-volume dynamical core for global models, Mon. Weather Rev., 132, 2293-2307, 2004.

Liousse, C., Penner, J. E., Chuang, C., Walton, J. J., Eddleman, H., and Cachier, H.: A global three-dimensional model study of carbonaceous aerosols, J. Geophys. Lett., 101, 19411-19432, 1996.

Matichuk, R. I., Colarco, P. R., Smith, J. A., and Toon, O. B.: Modeling the transport and optical properties of smoke aerosols from African savanna fires during the Southern African Regional Science Initiative campaign (SAFARI 2000), J. Geophys. Res., 112, D08203, doi:10.1029/2006JD007528, 2007.

Pack, D. W., Rice, C. J., Tressel, B. J., LeeWagner, C. J., and Oshika, E. M.: Civilian uses of surveillance satellites, Crosslink, 1(1), 2-8, 2000.

Pan, L., Gille, J. C., Edwards, D. P., Bailey, P. L., and Rodgers, C. D.: Retrieval of tropospheric carbon monoxide for the MOPITT experiment, J. Geophys. Res., 103, 32 277-32 290, 1998.

Pétron, G., Granier, C., Khattatov, B., Yudin, V., Lamarque, J., Emmons, L., Gille, J., and Edwards, D. P.: Monthly CO surface sources inventory based on the 20002001 MOPITT satellite data, Geophys. Res. Lett., 31, L21107, doi:10.1029/2004GL020560, 2004.

Pickering, K. E., Thompson, A. M., Wang, Y., Tao, W. K., McNamara, D. P., Kirchhof, J. H., Heikes, B. G., Sachse, G. W., Bradshaw, J. D. , Gregory, G. L., and Blake, D. R.: Convective transport of biomass burning emissions over Brazil during TRACEA, J. Geophys. Res., 101(D19), 23 993-24 012, 1996.

Piketh, S. J., Elias, T., and Stein, D. C.: SAFARI 2000 JRA Aerocommander Trace Gas, Aerosol, and CCN Data, Dry Season 2000. Data set, available online: http://www.daac.ornl.gov from Oak Ridge National Laboratory Distributed Active Archive Center, Oak Ridge, Tennessee, USA, doi:10.3334/ORNLDAAC/713, 2004.
Prins, E. M. and Menzel, W. P.: Geostationary satellite estimation of biomass burning in South America, Int. J. Remote Sens., 13, 2783-2799, 1992.

Prins, E. M., Feltz, J. M., Menzel, W. P., and Ward, D. E.: An overview of GEOS-8 diurnal fire and smoke results for SCARB and the 1995 fire season in South America, J. Geophys. Res., 103(D24), 31 821-31 836, 1998.

Rasch, P. J., Coleman, D. B., Mahowald, N., Williamson, D. L., Lin, S. J., Boville, B. A., and Hess, P.: Characteristics of atmospheric transport using three numerical formulations for atmospheric dynamics in a single GCM framework, J. Climate, 19, 2243-2266, 2006.

Rosenfeld, D., Fromm, M., Trentmann, J., Luderer, G., Andreae, M. O., and Servranckx, R.: The Chisholm firestorm: observed microstructure, precipitation and lightning activity of a pyrocumulonimbus, Atmos. Chem. Phys., 7, 645-659, 2007, http://www.atmos-chem-phys.net/7/645/2007/.

Sinha, P., Jaegle, L., Hobbs, P. V., and Liang, Q.: Transport of biomass burning emissions from Southern Africa, J. Geophys. Res., 109, D20204, doi:10.1029/2004JD005044, 2004.

Staudt, A. C., Jacob, D. J., Logan, J. A., Bachiochi, D., Krishnamurti, T. N., and Sachse, G. W.: Continental sources, transoceanic transport, and interhemispheric exchange of carbon monoxide over the Pacific, J. Geophys. Res., 106, 32 571-32 590, 2001.

Swap, R. J., Annegarn, H. J., Suttles, T., King, M. D., Platnick, S., Privette, J. L., and Scholes, R. J.: Africa burning: A thematic analysis of the Southern African Regional Science Initiative (SAFARI 2000), J. Geophys. Res., 108, 8465, doi:10.1029/2003JD003747, 2003.

Turquety, S., Logan, J. A., Jacob, D. J., et al.: Inventory of boreal fire emissions for North America in 2004, Importance of peat burning and pyroconvective injection, J. Geophys. Res., 112, 12S03, doi:10.1029/2006JD007281, 2007.

van der Werf, G. R., Randerson, J. T., Giglio, L., Collatz, G. J., Kasibhatla, P. S., and Arellano Jr., A. F.: Interannual variability in global biomass burning emissions from 1997 to 2004, Atmos. Chem. Phys., 6, 3423-3441, 2006,

http://www.atmos-chem-phys.net/6/3423/2006/.

Wang, J., Christopher, S. A., Nair, U. S., Reid, J. S., Prins, E. M., Szykman, J., and Hand, J. L.: Mesoscale modeling of Central American smoke transport to the United States: 1. Top down assessment of emission strength and diurnal variation impacts, J. Geophys. Res., 111, D05S17, doi:10.1029/2005JD006416, 2006.

Wang, Y., Tao, W. K., Pickering, K. E., Thompson, A. M., Adler, R., Simpson, J., Keehn, P., and Lai, G.: Mesoscale model (MM5) simulation of TRACE and PRESTORM Convective Systems and Associated Tracer Transport, J. Geophys. Res., 101, $24013-$ 24027, 1996.

Zhang, G. J. and McFarlane, N. A.: Sensitivity of climate simulations to the parameterization of cumulus convection in the Canadian Climate Centre General Circulation Model, Atmos. Ocean, 33, 407-446, 1995. 